\title{
Optimalisasi Sayuran Buncis Sebagai Upaya Peningkatan Perekonomian Keluarga di Desa Meunasah Kulam
}

\author{
Sari Wardani1*, Cut Rahmawati², Rina Mirdayanti ${ }^{3}$, Meliyani Safitri Dewi ${ }^{4}$ \\ 1Jurusan Peternakan, Fakultas Pertanian, Universitas Abulyatama, Aceh \\ ${ }^{2}$ Jurusan Teknik Sipil, Fakultas Teknik, Universitas Abulyatama, Aceh \\ ${ }^{3}$ Jurusan FKIP Fisika, Fakultas Ilmu dan Keguruan, Universitas Abulyatama, Aceh \\ 4Jurusan Ekonomi Manajemen, Fakultas Ekonomi, Universitas Abulyatama, Aceh \\ * e-mail : sariwardani_peternakan@abulyatama.ac.id
}

\begin{abstract}
Meunasah Kulam Village is located in North Aceh Regency of Aceh Province with the main income of the people sourced from the agricultural sector, namely farming and raising. In the mass Covid-19 pandemic, people are required to carry out activities at home in order to break the chain of spread of Covid-19 as a result of the decrease in income in the community. The solution offered through community service activities is to carry out mentoring of home business activities so as to increase family production. Home business produced crispy beans products. The activity was held in Geucik house which was attended by housewives. The activity stage consists of the preparation stage, the product processing stage and the product marketing stage. The conclusion of this community service activity is that mothers become more skilled in processing foodstuffs, especially green beans vegetables into more interesting products and preferably the community especially children so as to improve the family economy, especially during the covid-19 pandemic.
\end{abstract}

Keywords: Meunasah Kulam Village, Home Business, Crispy Beans, Vegetables Chickpeas, Improving Family Economy

\begin{abstract}
Abstrak
Desa Meunasah Kulam terletak di Kabupaten Aceh Utara Provinsi Aceh dengan penghasilan utama masyarakatnya bersumber dari sektor pertanian yaitu bertani dan beternak. Di massa pandemi Covid-19 masyarakat diharuskan untuk melaksanakan kegiatan di rumah supaya dapat memutus mata rantai penyebaran Covid-19 akibatnya terjadi penurunan pendapatan di masyarakat. Solusi yang ditawarkan melalui kegiatan pengabdian kepada masyarakat ini adalah dengan melaksanakan pendampingan kegiatan usaha rumahan sehingga dapat meningkatkan penghasilkan keluarga. Usaha rumahan yang di dihasilkan yaitu produk crispy beans. Kegiatan dilaksanakan di rumah Geucikyang dihadiri oleh ibu - ibu rumah tangga. Tahapan kegiatan terdiri dari tahap persiapan, tahap pengolahan produk dan tahap pemasaran produk. Kesimpulan kegiatan pengabdian masyarakat ini adalah ibu - ibu menjadi lebih terampil dalam mengolah bahan makanan khususnya sayuran buncis menjadi produk yang lebih menarik dan lebih disukai masyarakat khusunya anak - anak sehingga dapat meningkatkan perekonomian keluarga terutama dimasa pandemi covid-19.
\end{abstract}

Kata kunci: Desa Meunasah Kulam, Usaha Rumahan, Crispy Beans, Sayuran Buncis, Peningkatan Perekonomian Keluarga

\section{PENDAHULUAN}

Pandemi Covid-19 yang terjadi saat ini juga berdampak bagi negara Indonesia khususnya pada sektor perekonomian dengan terjadi pemutusan hubungan kerja yang berakibat meningkatnya jumlah pengangguran. Berbagai usaha telah dilakukan oleh masyarakat dalam pemenuhan kebutuhan untuk keluarga setiap harinya. Salah satu kegiatan yang dengan cepat dapat meningkatkan perekonomian keluarga adalah dengan melakukan bisnis tetapi dibutuhkan kreativitas yang tinggi agar bisnis yang dijalankan dapat bertahan lama. Salah satu nya dengan menciptakan produk - produk yang belum banyak di pasaran dan terus melakukan inovasi inovasi agar produk yang di hasilkan dapat memenuhi kebutuhan pasar. Demi memenuhi kebutuhan rumah tangga mengharuskan seorang ibu berpikir untuk melakukan kegiatan yang dapat membantu perekonomian keluarga (Majid, 2020; Puspita \& Komarudin, 2021). Inovasi yang dapat dengan mudah kita kembangkan adalah melakukan usaha yang berasal langsung dari rumah dengan menggunakan potensi yang ada disekitar rumah. Sehingga modal awal yang kita 
butuhkan untuk memulai usaha tidak terlalu besar dan sesuai dengan arahan pemerintah agar masyarakat berkegiatan dari rumah selama masa pandemi Covid-19. Pandemi Covid-19 juga mempunyai dampak terhadap masyarakat Aceh khususnya desa Meunasah Kulam, kecamatan Kuta Makmur Kabupaten Aceh Utara yaitu terhadap menurunnya pendapatan keluarga secara signifikan. Hal ini dikarenakan selama pandemi Covid-19 pemerintah mengharuskan masyarakat untuk dapat bekerja dari rumah agar dapat memutus rantai penyebaran Covid-19.

Selama masa pandemik Covid-19 ibu - ibu di Desa Meunasah Kulam hanya dapat berkegiatan dari rumah dengan menanam tanaman sayuran seperti bayam, sawi, kangkung, cabai, kacang panjang serta buncis. Budidaya tanaman dilakukan menggunakan media polibag sehingga tidak membutuhkan lahan yang luas serta dapat di kontrol setiap hari. Hasil panen sayuran biasanya digunakan untuk memenuhi kebutuhan sehari - hari karena pendapatan keluarga mengalami penurunan selama massa Covid-19. Ketika hasil panennya banyak sayuran akan dijual ke pasar, tetapi pendapatannya tidak maksimal dikarenakan harga jual sayuran yang rendah dan massa simpan sayur yang relatif singkat sehingga sayuran mudah menjadi busuk. Alternatif yang dapat dapat dilakukan agar sayuran tidak terbuang karena membusuk adalah dengan mengolah sayuran tersebut menjadi produk makanan yang mempunyai daya simpan yang lebih lama. Makanan ringan atau keripik merupakan salah satu makanan yang mempunyai daya simpan yang lama jika diolah dengan metode yang tepat. Hampir seluruh kalangan masyarakat menyukai makanan ringan yang umumnya dikenal dengan cemilan. Bisnis makanan ringan atau cemilan merupakan bisnis yang sangat menjanjikan dimasa pandemic Covid-19 karena dapat dilakukan dari rumah dan tidak membutuhkan modal yang besar.

Usaha rumahan yaitu kegiatan yang dikerjakan langsung dari rumah sehingga dapat mengurangi modal yang dibutuhkan dalam memulai suatu usaha. Jenis usaha rumahan saat ini sudah berkembang sangat pesat. Jenis usaha rumahan ada yang langsung mengolah bahan baku sampai menghasilkan produk, jenis usaha rumahan yang hanya menjual bahan baku saja dan jenis usaha rumahan yang menjual produk saja. Berikut beberapa bisnis yang dapat dijadikan usaha rumahan untuk ibu rumah tangga yaitu usaha kuliner, usaha MLM, usaha di bidang fashion dan usaha dibidang perlengkapan bayi. Salah satu jenis usaha rumahan yang mengolah bahan baku hingga menghasilkan produk adalah usaha dibidang kuliner atau makanan dan merupakan bisnis yang paling memungkinkan dan mudah untuk dilakukan oleh seorang ibu rumah tangga hal ini dikarenakan kemampuan memasak yang pasti dimiliki oleh seorang ibu rumah tangga. Ketrampilan dasar yang dimiliki ini merupakan modal awal yang sangat dibutuhkan untuk memulai usaha (Elburdah et al., 2021).

Usaha rumahan atau yang umumnya dikenal dengan home industry merupakan salah satu wirausaha yang paling banyak ditekuni oleh masyarakat di masa pandemik Covid-19 khususnya oleh ibu - ibu dan remaja putri. Beberapa alasan yang diutarakan oleh ibu - ibu dalam memulai usaha rumahan yaitu usaha rumahan merupakan usaha yang tidak membutuhkan modal yang besar, usaha rumahan dapat dimulai dari suatu hobi yang ternyata mampu menambah penghasilan jika ditekuni dengan serius (Diana \& Laila, 2020). Industri rumahan adalah suatu kegiatan produktif yang didirikan oleh seseorang dan/ atau berbadan hukum yang memenuhi kriteria kelompok industri mikro sebagaimana diatur didalam UU RI No. 20 tahun 2008 pasal 1. Usaha rumahan adalah kegiatan ekonomi rakyat berskala kecil dan dapat dilakukan secara tradisional sehingga kebanyakan usaha rumahan ini belum terdaftar atau belum tercatat atau belum berbadan hukum. Usaha rumahan umumnya dikelola langsung oleh anggota keluarga atau gabungan dari beberapa kerabat dekat. Usaha rumahan mempunyai beberapa karakteristik, yang pertama usaha yang bersifat ekstraktif yang menggunakan bahan baku setegah untuk menhasilkan suatu produk. Yang kedua adalah usaha rumahan yang mempunyai tenaga kerja maksimal 19 orang. Batasan tenaga kerja ditentukan karena tenaga kerja yang terlalu banyak akan mempengaruhi pembiayaan. Yang ketiga adalah usaha rumahan yang tidak bergantung pada kondisi apapun seperti bahan baku, permintaan pasar, jumlah karyawan ataupun teknologi pengolahan yang digunakan sehingga usaha rumahan ini mempunyai sifat yang sangat fleksibel. Peran dan manfaat dari usaha rumahan diantaranya sebagai alternatif penghasilan bagi keluarga 
karena tidak menyita waktu sehingga permasalah ekonomi keluarga dapat teratasi dan usaha rumahan juga berperan dalam mengurangi angka kemiskinan dan pengganguran karena usaha rumahan dapat membuka lapangan pekerjaan (Majid, 2020).

Indonesia termasuk negara tropis yang menghasilkan bahan pangan hayati yang beragam sehingga masyarakat tidak kesulitan dalam pemenuhan bahan pangan untuk dikonsumsi sepanjang waktu. Aneka sayuran dapat tumbuh sepanjang waktu tanpa danya periode musiman seperti sayuran buncis, kacang panjang, terong, kangkung, brokoli dan yang lain dapat kita panen kapan saja. Buncis (Phaseolus vulgaris L.) termasuk kedalam kelompok tanaman yang mudah dibudidayakan di Indonesia karena tanaman buncis hanya membutuhkan sinar matahari selama dua belas jam sehari dalam proses pembungaannya. Sayuran buncis dapat dipanen dengan waktu yang relatif singkat yairu setelah 2 bulan masa tanam. Sayuran buncis kaya akan senyawa kimia yang sangat bermanfaat bagi kesehatan. Kandungan senyawa kimia pada sayuran buncis banyak terdapat pada bagian bijinya yaitu senyawa glukoprotein, tripsin inhibitor, hemaglutinin, $\beta$ sitosterol, stigmasterol, alantonin, dan inositol sedangkan pada bagian kulit mengandung senyawa leukopelargonidin, kuersetin, pelargonidin, sianidin, kaempferol, petunidin, delfinidin, malvidin, dan mirsetin (Rachmawani \& Oktarlina, 2017). Sayuran buncis selain digunakan dalam pengobatan antidiabetes tetapi dapat digunakan sebagai obat dalam pencegahan kanker usus, kanker payudara dan juga berfungsi untuk melancarkan pencernaan karena buncis mempunyai kandungan serat yang tinggi (Maripa et al., 2019).

Buncis dapat dikonsumsi secara langsung atau dimasak sebagai sayuran. Buncis yang dipetik ketika masih muda dan dikonsumsi secara langsung mengandung nilai gizi yang tinggi sehingga sangat menyehatkan bagi kesehatan tubuh. Masyarakat yang menggunakan pola makan vegetarian sangat dianjurkan untuk mengkonsumsi sayuran buncis karena kandungan protein yang sangat tinggi dan rendah kalori sehingga juga sangat sesuai untuk masyarakat yang sedang menjalankan program diet (Musdalifah \& Napitupulu, 2020). Beberapa manfaat buncis diantaranya sebagai bahan sayuran hal ini dikarenakan buncis mengandung vitamin dan mineral yang sangat dibutuhkan oleh tubuh sehingga kesehatan tubuh manusia dapat terjaga dengan baik serta bermanfaat sebagai sumber protein yang sangat murah dan harganya sangat terjangkau. Kandungan lainya pada sayuran buncis adalah karbohidrat, vitamin dan mineral. Buncis dapat dimanfaatkan sebagai bahan pengobatan terutama sebagai obat untuk menurunkan kolestrol, hipolipedemia, hipoglikemih dan diuretik. Buncis yang masih muda terkandung zat gizi dan glukosida yang dapat meningkatkan kinerja limpa serta berkhasiat sebagai antikanker. Buncis juga dapat dimanfaatkan untuk mengobati atau mencegah penyakit Diabetes Melitus yang berasal dari zat B-sitosterol dan Stigmasterol yang terkandung dalam buncis. Manfaat lainnya dari tanaman buncis adalah sebagai komoditas agroindustri dan agrobisnis hal ini didasari karena dengan melakukan budi daya tanaman buncis dapat meningkatkan pendapatan dan menambah penghasilan.

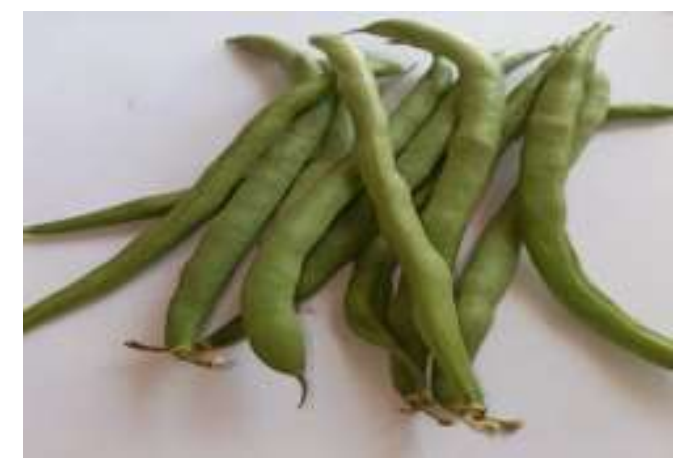

Gambar 1. Sayuran Buncis

Sayuran buncis mengandung vitamin dan nutrisi yang sangat dibutuhkan tubuh untuk meningkatkan kesehatan. Hasil penelitian menyatakan bahwa kandungan senyawa flavonoid yang terdapat didalam sayuran buncis mampu mengobati pasien diabetes melitus tipe 2 sehingga 
kinerja reseptor insulin dan kandungan fitosterol mengalami peningkatan yang dapat merangsang sekresi insulin dari pancreas (Rachmawani \& Oktarlina, 2017). Bahan makanan yang tinggi kandungan serat dan rendah glikemik salah satunya adalah sayuran buncis (Phaseolus vulgaris L). Senyawa bioaktif yang terkandung dalam sauran buncis berperan sebagai antidiabetes, yaitu senyawa flavonoid, beta sitosterol, stigmasterol, alkaloid, saponin, dan fenol (Maripa et al., 2019). Hasil penelitian lainnya mengemukakan bahwa pasien diabetes mellitus yang rutin mengkonsumsi buncis selama program diet dapat menurunkan glukosa darah jika dibandingkan dengan pasien diebetes mellitus yang tidak mengkonsumsi buncis selama program diet, hasil penelitian menyimpulkan bahwa efek antihyperglycemic yang terdapat di dalam sayuran buncis dapat dijadikan obat alternative bagi pasien diabetes mellitus (Pari \& Venkateswaran, 2003). Hasil penelitian lainnya menyatakan bahwa buncis dapat diolah sebagai obat antidiabetes dikarenakan buncis kaya kandungan senyawa bioaktif yang mampu menghidrolisis enzim sehingga protein membentuk senyawa peptida bioaktif yang mengandung antioksidan yang yang tinggi sehingga usus tidak banyak menyerap glukosa dan merangsang sekresi insulin (de Souza Rocha et al., 2015; Maripa et al., 2019). Sayuran buncis dapat digunakan sebagai obat antikanker karena mengandung senyawa glucosamine (Chan et al., 2015).

Sayuran buncis umumnya hanya diolah menjadi tumisan buncis yang cita rasanya kurang diminati anak- anak. Salah satu usaha yang dapat dilakukan adalah mengolahan sayuran buncis menjadi produk yang bernilai jual tinggi sehingga mampu menambah pendapatan keluarga. Produk makanan kering yang sangat digemari dan dikenal secara luas oleh masyarakat Indonesia adalah kerupuk. Kerupuk dapat dikonsumsi secara langsung atau sebagai makanan kecil yang dapat dikonsumsi dengan makanan berat seperti nasi. Hampir tidak ada masyarakat yang tidak menyukai makanan ringan ini. Sehingga sangat wajar jika industri atau usaha yang bergerak dalam memproduksi kerupuk semakin banyak kita jumpai karena permintaan pasar yang meningkat setiap harinya. Baik industri besar atau industri kecil semuanya berlomba untuk menghasilkan produk kerupuk yang mempunyai kualitas dan cita rasa yang nikmat (Subagya et al., 2018). Kerupuk termasuk kedalam makanan kering yang tinggi kandungan pati dikarenakan terbuat dari bahan dasar tepung. Tepung yang umum digunakan dalam proses pembuatan kerupuk adalah tepung tapioka, tepung jagung, tepung kentang dan tepung beras. Perbedaan olahan berbagai varian kerupuk pada dasarnya terdapat pada tambahan jenis bumbu - bumbu yang digunakan saat proses pemasakan kerupuk. Kualitas kerupuk dapat dinilai dari mutu kerupuk yaitu tekstur, cita rasa dan penampakannya. Untuk menambah citarasa dan memperkaya kandungan protein pada kerupuk dapat ditambahkan olahan berbahan dasar hewani atau sayuran (Kawiji, 2009). Kandungan gizi sayuran buncis ditampilkan pada Tabel 1.

Tabel 1. Kandungan gizi sayuran buncis

\begin{tabular}{clc}
\hline No & \multicolumn{1}{c}{ Zat Gizi } & Jumlah Kandungan gizi \\
\hline 1 & Energi/kalori & $35 \mathrm{kal}$ \\
2 & Protein & 2,4 gram \\
3 & Lemak & 0,2 gram \\
4 & Karbohidrat & 7,7 gram \\
5 & Kalsium & 6,5 gram \\
6 & Fosfor & 4,4 gram \\
7 & Serat & 1,2 gram \\
8 & Besi & 1,2 gram \\
9 & Vitamin A & $630,0 \mathrm{SI}$ \\
10 & Vitamin B1 & $0,08 \mathrm{mg}$ \\
11 & Vitamin B2 & $0,1 \mathrm{mg}$ \\
12 & Vitamin B3 & $0,7 \mathrm{mg}$ \\
13 & Vitamin C & $19,0 \mathrm{mg}$ \\
14 & Air & $89 \mathrm{~g}$ \\
\hline
\end{tabular}

Sumber: (Waluyo, 2013) 
Karakteristik kimia buncis segar terdiri dari 94,195 \% kadar air, 13,26\% berat kering kadar abu, kadar serat kasar 23,43\% berat kering dan vitamin C 15,51 mg/100 gr berat kering dengan kadar $\beta$-karoten 2202,17 ppm (Setyawan \& Widaningrum, 2017). Sayuran segar jika disimpan dalam waktu yang lama akan cepat rusak atau layu, sehingga diperlukan metode yang mampu mengolah sayuran segar menjadi produk yang dapat disimpan lebih lama serta mempunyai gizi dan nilai ekonomis yang tinggi. Kerupuk sayur yang sering kita jumpai dipasaran adalah kerupuk bayam, kerupuk wortel kerupuk jagung, kerupuk daun singkong dan kerupuk kentang (Setyawan \& Widaningrum, 2017; Subagya et al., 2018). Kegiatan pengabdian kepada masyarakat bertujuan untuk melaksanakan pendampingan kepada ibu - ibu rumah tangga dalam mengolah sayuran buncis menjadi produk makanan yang menyehatkan, mempunyai cita rasa yang nikmat serta mempunyai nilai ekonomis yang tinggi sehingga mampu meningkatkan perekonomian keluarga selama masa pandemi Covid-19.

\section{METODE}

Metode pengabdian kepada masyarakat dilaksanakan menggunakan teknik pengumpulan data yang terdiri dari teknik observasi dan teknik wawancara. Tahapan yang pertama adalah observasi dengan mengamati kondisi keluarga di desa Meunasah Kulam sehingga dapat diupayakan kegiatan yang dapat di laksanakan dari rumah selama massa pandemi covid-19. Tahap kedua adalah wawancara untuk mengetahui permasalahan yang dihadapi ibu - ibu rumah tangga selama masa pandemik Covid-19. Setelah observasi dan berdiskusi dengan ibu - ibu rumah tangga maka solusi yang ditawarkan adalah melakukan kegiatan pendampingan usaha rumahan dimulai dari pelatihan pembuatan produk sampai dengan proses pengemasan dan penjualan produk. Kegiatan usaha rumahan yang akan dilaksanakan adalah menggolah sayuran buncis menjadi produk Crispy Beans.

Tahapan pengolahan crispy beans dilaksanakan dengan mempraktekkan secara langsung bersama ibu - ibu. Bahan yang digunakan dalam proses pembuatan Crispy Beans terdiri dari sayuran buncis, tepung terigu, tepung tapioka, merica, garam, penyedap rasa dan pewarna makanan. Proses pengolahannya pertama-tama dengan memilih sayuran buncis yang mempunyai berkualitas terbaik, kemudian sayuran buncis dibelah menjadi dua, dicuci hingga bersih dan ditiriskan. Proses kedua adalah pembuatan adonan tepung yang terdiri dari tepung kanji dan tepung terigu dengan perbandingan yang 1: 1,5, kemudian ditambahkan penyedap rasa, merica bubuk, garam dan air secukupnya, selanjutnya diaduk sampai rata dan ditambahkan pewarna makanan berwarna kuning secukupnya. Proses terakhir adalah proses penggorengan yaitu buncis yang telah dibagi dua kemudian dimasukkan kedalam adonan digoreng setengah crispy selanjutnya diangkat dan ditiriskan, didiamkan selama 5 menit kemudian digoreng kembali hingga benar - benar crispy, selanjutnya ditiriskan dan dibiarkan sampai benar - benar dingin baru dilakukan proses pengemasan. Proses pengemasan dengan memasukkan Crispy Beans ke dalam plastik kemasan yang sudah diberi label dengan berat 250 gr perkemasan.

\section{HASIL DAN PEMBAHASAN}

Kegiatan pengabdian masyarakat telah selesai dilaksanakan di desa Meunasah Kulam Kecamatan Kuta makmur Kabupaten Aceh Utara dengan peserta terdiri dari ibu - ibu rumah tangga sebanyak delapan orang. Kondisi desa yang aman dan tentram membuat masyarakat desa yang peduli serta saling bergotong royong. Desa Meunasah Kulam merupakan salah satu desa yang terletak di Kecamatan Kuta Makmur Kabupaten Aceh Utara Provinsi Aceh. Wilayah

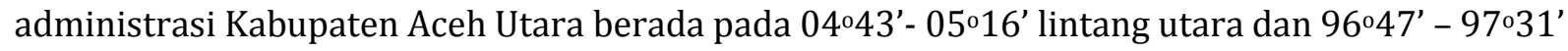
lintang timur. Secara administratif Kabupaten Aceh Utara berbatasan dengan Kota Lhokseumawe dan selat malaka dibagian utara, berbatasan dengan Kabupaten Bener Meriah dibagian selatan, berbatasan dengan Kabupaten Aceh Timur di bagian timur dan berbatasan dengan kabupaten Bireuen dibagian barat. Wilayah Kabupaten Aceh Utara terdiri dari 27 Kecamatan dan 852 Gampong dengan luas wilayah keseluruhan $\pm 3.296,86 \mathrm{~km}^{2}$ (BPS, 2021). 
Kecamatan Kuta Makmur dengan Ibukota kecamatan Buloh Blang Ara memiliki luas 151,32 $\mathrm{km}^{2}$ atau 15,132 Ha. Kecamatan Kuta Makmur terdiri dari 3 pemukinan, 39 desa dengan jumlah penduduk 26.379 jiwa. Secara geografis sebelah utara Kecamatan Kuta Makmur berbatasan dengan Kecamatan Nisam dan Kota Lhokseumawe, sebelah selatan berbatasan dengan Kecamatan Syamtalira Bayu dan Kecamatan Simpang Keramat, sebelah Barat berbatasan dengan Kecamatan Nisam dan sebelah Timur berbatasan dengan Kecamatan Simpang Keramat dan Kota Lhokseumawe (BPS, 2020).

Kegiatan pengabdian dilaksanakan di desa Meunasah Kulam yang mempunyai luas desa sebesar $130 \mathrm{~km}^{2}$ yang berupa dataran. Desa Meunasah kulam masuk kedalam daerah pemerintahan pemukiman Beureughang dengan jumlah dusun sebanyak 3 dusun. Masyarakat yang bermukim di desa Meunasah Kulam harus menempuh perjalanan sejauh $5 \mathrm{~km}$ untuk mencapai Ibukota kecamatan dan sejauh $15 \mathrm{~km}$ untuk mencapai Ibukota kabupaten. Pertumbuhan jumlah penduduk pada desa Meunasah Kulam mengalami peningkatan setiap tahunnya dimana pada tahun 2015 jumlah penduduk nya adalah 447 jiwa, kemudian meningkat di tahun 2017 sebesar 470 jiwa dan terus meningkat di tahun 2019 dengan jumlah penduduk 483 jiwa. Pada tahun 2019 jumlah penduduk yang berjenis kelamin laki - laki sebanyak 221 jiwa dan berkelamin perempuan sebanyak 262 jiwa. Struktur organisasi pada Desa Meunasah Kulam di pimpin oleh seorang kepala desa yang dibantu oleh tiga kepala dusun yaitu dusun aman, dusun Makmur dan dusun subur. Setiap dusun dibantu oleh tiga kepala yaitu kepala bidang pemerintahan, kepala bidang pembangunan dan kepala bidang umum. Sumber penghasilan utama masyarakat Meunasah Kulam bersumber dari pertanian, perdagangan serta jasa dan lainnya. Dari sub sektor pertanian yang paling banyak bersumber dari tanaman pangan, sedangkan dari sub perdagangan bersumber dari kegiatan industry anyaman (BPS, 2020).

Selama kegiatan pengabdian berlangsung tetap mengikuti protocol kesehatan Covid-19 dengan membatasi jumlah peserta, menjaga jarak dan menggunakan masker. Hasil observasi dan wawancara awal diperoleh bahwa 86\% ibu - ibu mengalami kesulitaan dalam pemenuhan kebutuhan sehari - hari dikarenakan penghasilan yang tidak menentu selama massa pandemi Covid-19 dan ditambahkan dengan himbauan dari pemerintah yang mengharuskan masyarakat berkegiatan dari rumah sehingga ibu - ibu sulit untuk melakukan rutinitas seperti biasanya.

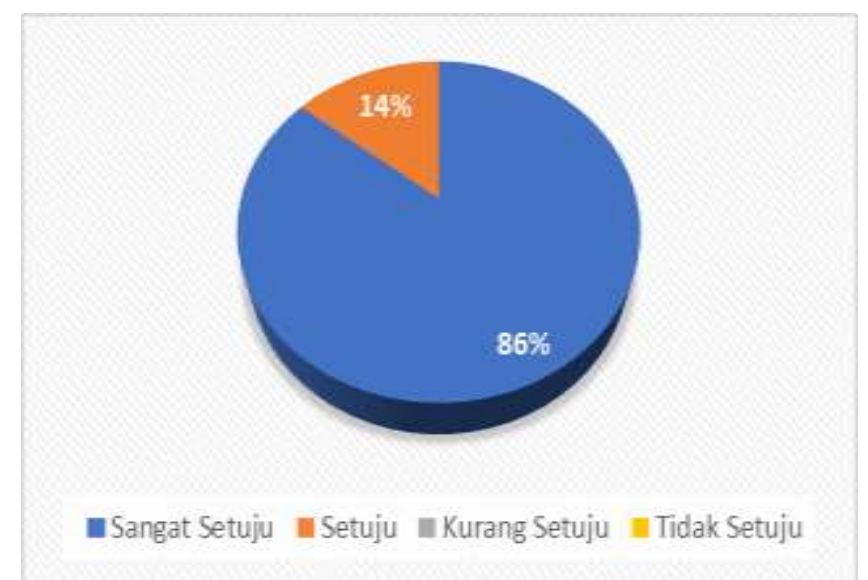

Gambar 2. Hasil persentase kesulitan perekonomian keluarga di masa pandemik Covid-19

Solusi yang ditawarkan kepada ibu - ibu adalah dengan melaksanakan kegiatan usaha rumahan karena mudah dilaksanakan serta modal yang dibutuhkan tidak banyak sehingga dapat menambah penghasilan keluarga dan dapat mengatasi permasalahan perekonomian dalam keluarga. Hasil diskusi dengan ibu - ibu maka usaha rumahan yang dipilih adalah menggolah sayuran buncis menjadi produk Crispy Beans hal ini didasari karena bahan baku mudah diperoleh dan harga sayuran buncis lebih murah jika dibandingkan dengan sayuran yang lain.

Kegiatan penggolahan produk Crispy Beans dilaksanakan di rumah Geucik. Tahap awal adalah memberikan penjelasan terkait manfaat sayuran buncis dan prospek usaha rumahan dan 
dilanjutkan dengan mendemokan proses menggolah sayuran buncis menjadi produk Crispy Beans yang langsung dipraktekkan oleh ibu - ibu. Selama mengikuti kegiatan ibu - ibu sangat antusias dalam mendengarkan penjelasan dan mempelajari proses pengolahan produk Crispy Beans sehingga selama kegiatan berlangsung tidak ditemukan kendala. Kualitas produk Crispy Beans sangat ditentukan dari bahan utama yang digunakan yaitu harus menggunakan tepung yang mempunyai kualitas yang baik ditandai dengan tepung mempunyai penampakan putih, kering, bersih dan tidak berbau asam serta ditentukan juga dari komposisi dalam pencampuran bahan utama dengan sayuran buncis. Perbandingan penggunaan tepung kanji dan tepung terigu yang sesuai takaran akan menghasilkan produk yang sangat baik. Hasil penelitian lainnya menyatakan bahwa responden sangat suka terhadap kualitas kerupuk terubuk yang menggunakan $150 \mathrm{gr}$ tepung terigu, $100 \mathrm{gr}$ tepung tapioka dan 150 gr sayuran sehingga menghasilkan produk yang memiliki kualitas warna, aroma, rasa dan tekstur pada pembulatan nilai 4 (Chaniago et al., 2019). Produk Crispy Beans yang dihasilkan kemudian dikemas dan diberi label agar dapat menambah minat pembeli. Produk yang dipasarkan dijual dengan harga Rp 5.000., perbungkus.

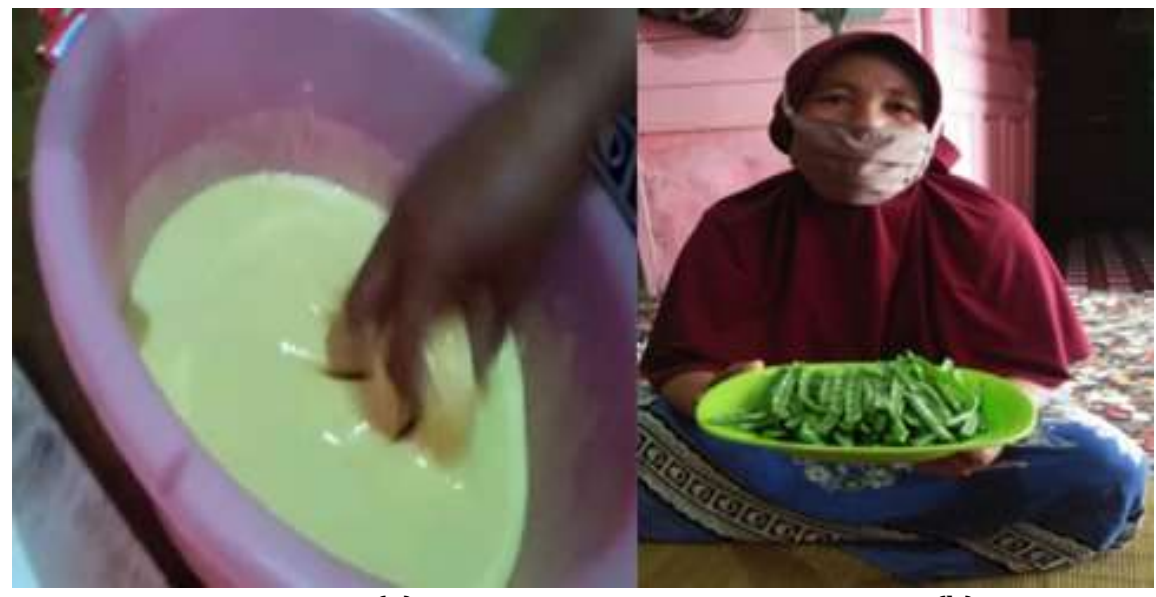

(a)

(b)

Gambar 3. Proses pembuatan adonan Crispy Beans (a); Bahan baku Crispy Beans (b)

Diakhir kegiatan dilakukan wawancara yang diwakili oleh ibu Geucik yang menyatakan bahwa ibu - ibu sangat senang dapat mengikuti kegiatan pengabdian ini karena dapat menambah wawasan dalam memulai usaha rumahan, sehingga dapat menambah penghasilan keluarga selama massa pandemi dan ibu - ibu juga akan terus melanjutkan usaha rumahan Crispy Beans menjadi produk jajanan yang sehat serta akan terus berinovasi menciptakan produk Crispy dengan menggunakan bahan baku atau sayuran yang berbeda.

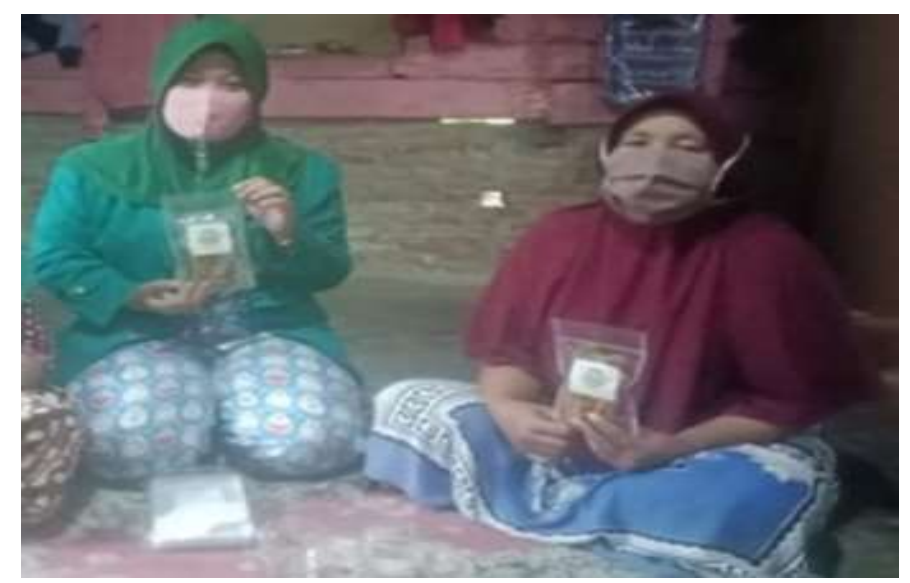

Gambar 4. Produk Crispy Beans yang siap dipasarkan 


\section{KESIMPULAN}

Kesimpulan dari kegiatan pengabdian ini adalah

1. Ibu - ibu rumah tangga di desa Meunasah Kulam lebih memahami prospek usaha rumahan dalam peningkatan perekonomian keluarga.

2. Ibu - ibu rumah tangga memiliki peningkatan kemampuan dalam mendesain dan memasarkan produk usaha rumahan.

3. Pendampingan usaha rumahan akan terus berlanjut dengan berinovasi dalam menciptakan produk jajanan yang sehat dan bergizi.

\section{UCAPAN TERIMA KASIH}

Ucapan terima kasih terutama ditujukan kepada Universitas Abulyatama dan Desa Meunasah Kulam Kecamatan Kuta Makmur Kabupaten Aceh Utara Provinsi Aceh yang telah memberikan izin sehingga pengabdian ini berjalan dengan sukses dan sesuai target yang diharapkan. Ucapan terima kasih juga disampaikan kepada ibu - ibu rumah tangga dan masyarakat di desa Meunasah Kulam yang sangat antusias dalam mengikuti kegiatan pengabdian ini.

\section{DAFTAR PUSTAKA}

BPS, A. U. (2020). Kecamatan Kuta Makmur Dalam Angka 2020. BPS Kabupaten Aceh Utara. BPS, A. U. (2021). Kabupaten Aceh Utara Dalam Angga 2021. BPS Kabupaten Aceh Utara.

Chan, Y. S., Xia, L., \& Ng, T. B. (2015). A Glucosamine-Specific Lectin from Green Dragon No. 8 Beans (Phaseolus vulgaris) Induced Apoptosis on Nasopharyngeal Carcinoma Cells. https://doi.org/10.1155/2015/760539

Chaniago, R., Lamusu, D., \& Samaduri, L. (2019). Daya Kembang Dan Sifat Organoleptik Kerupuk Terubuk ( Saccharum edule Hasskarl) The Combination Of Wheat Flour And Tapioca Flour To The Ability To Swell And Organoleptic Properties Of Terubuk ( Saccharum edule Hasskarl ) Cracers. Jurnal Pengolahan Pangan, 4(1), 1-8. http://www.pengolahanpangan.jurnalpertanianunisapalu.com/index.php/pangan/article/v iew/20

de Souza Rocha, T., Hernandez, L. M. R., Mojica, L., Johnson, M. H., Chang, Y. K., \& González de Mejía, E. (2015). Germination of Phaseolus vulgaris and alcalase hydrolysis of its proteins produced bioactive peptides capable of improving markers related to type-2 diabetes in vitro. Food Research International, 76(P1), 150-159. https://doi.org/10.1016/j.foodres.2015.04.041

Diana, \& Laila, N. (2020). Strategi Pengembangan Usaha Home Industri Makanan Sebagai Peluang Pendapatan di Masa Pandemi Covid 19. Seminar Nasional Pengabdian Masyarakat LPPM UMJ, 169-178. http://jurnal.umj.ac.id/index.php/semnaskat

Elburdah, R. P., Pasaribu, V. L. D., Rahayu, S., Septiani, F., \& Metarini, R. R. A. (2021). Mompreneur Penopang Perekonomian Keluarga Di Masa Pandemi Covid-19 Dengan Bisnis Online Pada Kelurahan Pondok Benda. Jurnal Pengabdian Kepada Masyarakat, 2(1), 75-82. http://www.openjournal.unpam.ac.id/index.php/JAL/article/view/8776

Kawiji, K. (2009). Kajian Karakter Sensoris Dan Ekonomi Pada Kerupuk Sayur. Jurnal Teknologi Hasil Pertanian. https://doi.org/10.20961/jthp.v0i0.12878

Majid, N. (2020). Sosialisasi Peran Ibu Rumah Tangga Sebagai Pondasi Ketahanan Bangsa Di Tengah Covid-19 Pada Ibu Pkk Desa Badak Baru Kabupaten Kutai Kartanegara. Jurnal Pengabdian Masyarakat Ilmu Keguruan Dan Pendidikan, 3(2), 76-82. www.trilogi.ac.id

Maripa, B. R., Andayani, Y., \& Savalas, L. R. T. (2019). Uji Kualitas Obat Tradisional Antidiabetes Dari Buah Buncis Dan Buah Pare. Jurnal Penelitian Pendidikan IPA, 5(1), 73-77. https://doi.org/10.29303/jppipa.v5i1.177

Musdalifah, \& Napitupulu, M. (2020). Pengaruh Pupuk Kandang Sapi Dan Pupuk Gandasil B Terhadap Pertumbuhan Dan Hasil Tanaman Buncis ( Phaseolus vulgaris L ) Varietas Lebat-3. Jurnal Agrifor, $\quad$ XIX(1), 99-108. http://ejurnal.untag- 
smd.ac.id/index.php/AG/article/view/4618

Pari, L., \& Venkateswaran, S. (2003). Effect of an aqueous extract of Phaseolus vulgaris on the properties of tail tendon collagen of rats with streptozotocin-induced diabetes. Brazilian Journal of Medical and Biological Research, 36(7), 861-870. https://doi.org/10.1590/S0100879X2003000700006

Puspita, L., \& Komarudin, K. (2021). Peningkatan Ekonomi Masyarakat: Dampak Pemanfaatan Ampas Susu Kedelai Menjadi Nugget. DINAMISIA: Jurnal Pengabdian Kepada Masyarakat, 5(1), 1-9. https://doi.org/10.31849/dinamisia.v5i1.4105

Rachmawani, N. R., \& Oktarlina, R. Z. (2017). Khasiat Pemberian Buncis (Phaseolus vulgaris L .) sebagai Terapi Alternatif Diabetes Melitus Tipe 2. Majority.

Setyawan, N., \& Widaningrum, W. (2017). Pengaruh Suhu Penggorengan Vakum Dan Cara Pembumbuan Terhadap Karakteristik Keripik Wortel (Effect of vacuum frying temperature and various technique of flavoring on characteristics of carrot chips). Jurnal Penelitian Pascapanen Pertanian, 10(2), 104. https://doi.org/10.21082/jpasca.v10n2.2013.104-112

Subagya, A. W., Tamrin, T., Sugianti, C., \& Suhandy, D. (2018). Mempelajari Karakteristik Pengeringan Kerupuk Sayur. Jurnal Ilmiah Rekayasa Pertanian Dan Biosistem, 6(2), 172-180. https://doi.org/10.29303/jrpb.v6i2.79

Waluyo, N. D. D. (2013). kandungan gizi buncis. IPTEK Tanaman Sayuran, 02. http://balitsa.litbang.pertanian.go.id/ind/images/Iptek Sayuran/02.pdf 